\title{
Ion microprobe determination of sulfur isotope variations in iron sulfides from the Post / Betze sediment-hosted disseminated gold deposit, Nevada, USA
}

\author{
Greg B. Arehart, ${ }^{1, *}$ C. STEWARt Eldridge, ${ }^{2}$ StePhen L. Chryssoulis, ${ }^{3}$ Stephen E. Kesler ${ }^{1}$ \\ ${ }^{1}$ Department of Gcological Sciences, University of Michigan, Ann Arbor, MI 48109-1063, USA \\ ${ }^{2}$ Geology Department and Research School of Earth Sciences, Australian National University, GPO Box 4, Canberra, A.C.T. 2601, Australia \\ ${ }^{3}$ Process Mineralogy Section, Surface Science Western, London, Ontario, Canada N6A 5B8
}

(Received May 29, 1991; accepted in revised form September 27, 1992)

\begin{abstract}
Secondary ion mass spectrometric analyses of ore samples from the Post/Betze sedimenthosted disseminated gold deposit were utilized to constrain elemental distribution of Au and As in iron sulfide phases. Most of the Au was deposited very early in the paragenetic sequence. Although Au and As are covariant in arsenian pyrite, Au apparently was depleted much more rapidly from the hydrothermal solutions than was As.

Sensitive high-resolution ion microprobe (SHRIMP) sulfur isotope analyses of iron sulfides from the Post/Betze deposit vary widely from $\delta^{34} \mathrm{~S}=-29$ to $23 \%$ and provide important information on the origin of sulfur and constraints on depositional mechanisms. Ore solutions had high $\delta^{34} \mathrm{~S}$ values and were most likely derived, at least in part, from thermochemical reduction of lower Paleozoic seawater-derived sulfate, possibly bedded barite. Late-stage ore fluids $\left(\delta^{34} S_{\text {sultide }}=-12\right.$ to $-29 \%$ ) are extremely depleted in ${ }^{34} \mathrm{~S}$ relative to main-stage ore fluids $\left(\delta^{34} \mathrm{~S}_{\text {sulfide }}=16-23 \%\right)$. Although such low $\delta^{34} \mathrm{~S}$ values can be generated hypothetically from the original ore fluids by oxidation (possibly boiling), the stability of pyrite is compromised. Introduction of and mixing with Fe-rich fluids is necessary to deposit pyrite having low isotopic values.
\end{abstract}

\section{INTRODUCTION}

STABLE ISOTOPE MEASUREMENTS have yielded many insights into problems of ore deposit genesis. Variations in sulfur isotopes are of particular importance, as many metals occur as sulfides or associated with sulfides. Recent development of microanalytical techniques has allowed more detailed information to be gleaned from the available samples. This development has been especially useful for the study of sediment-hosted disseminated gold (SHDG) deposits because of their very fine-grained nature. Previous sulfur isotope studies of SHDG deposits have been based on bulk samples or mineral separates which, due to the fine-grained nature of the material, have not permitted estimation of the true range of isotopic compositions in these ores. The relevance of these measurements to the origin of SHDG deposits was further limited by a paucity of information on the location of $\mathrm{Au}$ within the ores.

Published $\delta^{34} \mathrm{~S}$ values of hydrothcrmal sulfides from SHDG deposits fall between 0 and $15 \%$. The variation in pyrite alone equals the range exhibited by all other sulfides (e.g., RYE, 1985). Diagenetic pyrite from the Roberts Mountains Formation, the rock unit which hosts much of the ore in north-central Nevada, has isotopic compositions similar to those reported for hydrothermal sulfides, leading to the suggestion that the bulk of the ore-forming sulfide was derived from this source (RYE, 1985). Sulfur also may have been derived either from igneous sources or from sedimentary sulfate, both of which are abundant locally in the Paleozoic section in many parts of Nevada.

* Present address: Geosciences/CMT-205, Argonne National Laboratory, Argonne, IL 60439, USA
The present study goes beyond previous investigations in that both $\mathrm{Au}$ and As contents and distributions in iron sulfides were determined, and the data were correlated with sulfur isotope measurements of the same grains. The data were obtained by ion microprobe, which offers the maximum in spatial resolution along with sample conservation. Although no single ion microprobe can determine $\mathrm{Au}$, As, and $\delta^{34} \mathrm{~S}$ at present, we used two instruments and made measurements on the same or adjacent spots. This approach allowed paired isotopic and trace-element analyses to be made of singlephase areas of closely intergrown arsenopyrite and pyrite or individual growth zones of pyrite or marcasite. The value of such in situ sulfur isotope and $\mathrm{Au}$ measurements on small portions of individual crystals has been demonstrated by MCKIBBEN and EldRIDGE (1990) and CHRYSSOUlis et al. (1989).

\section{LOCATION AND DISTRIBUTION OF GOLD IN SEDIMENT-HOSTED DISSEMINATED GOLD DEPOSITS}

The host mineral for Au SHDG deposits has been a subject of long-standing debate. WELLS and MULLENS (1973) showed that $\mathrm{Au}$ was associated with pyrite and arsenian pyrite and were among the first to attempt quantification of Au by utilizing electron microbeam techniques. Since that time, a number of papers have been published regarding the location of gold in rocks of SHDG deposits (RADTKE et al., 1972; RADTKE, 1985; HoFSTRA et al., 1988; BAKKEN et al., 1989). HAUSEN and PARK ( 1985) and HAUSEN et al. (1987) showed that there was no significant correlation between organic matter and $\mathrm{Au}$ at the Carlin deposit, based on comparative bulk assays. Although jasperoidal and siliceous ores are present in most SHDG (BAKKEN and EINAUDI, 1986; HOFSTRA et al., 1988), such ores are generally secondary in economic 
importance to ores contained in primary sulfide minerals or their weathered equivalents.

Textures observed in ore samples from a variety of SHDG deposits suggest that preexisting igneous and diagenetic pyrite acted as a local nucleation center for crystallization of the earliest minerals deposited from the hydrothermal solution (AREHART et al., 1993a). Many grains of euhedral arsenian pyrite have cores of anhedral pyrite, which contain no As or Au. Arsenic is most enriched in the very earliest overgrowth material and forms arsenopyrite in some places. Gold is enriched in the earliest overgrowth arsenian pyrite and therefore is slightly later than arsenopyrite in the paragenetic sequence.

Both AREHART et al. $(1991,1993 a)$ and BAKKEN et al. (1991) have shown that there is a very strong correlation on a microscopic scale between arsenian pyrite and $\mathrm{Au}$ from a number of SHDG deposits in Nevada. CHRYSSOULIS (1990) used the ion and proton microprobes to examine composite ore samples from a variety of ore types from several gold deposits in the Carlin trend and established that most $\mathrm{Au}$ was associated with pyrite. He determined that fine-grained arsenian pyrite and, to a lesser extent, marcasite, are the principal carriers of submicroscopic gold. In one of the ores examined by CHRYSSOULIS (1990), 74.1\% of the assayed Au $(8.77 \mathrm{~g} / t)$ was accounted for by "invisible gold" in pyrite and marcasite, supporting the conclusions drawn by WELLS and Mullens (1973)

Therefore, in SHDG deposits the majority of the mineable Au was deposited in sulfide ores (many of which have been subsequently oxidized by weathering), and a very high proportion of that $\mathrm{Au}$ is in arsenian pyrite. The data of FLEET et al. (1988), Cathlineau et al. (1988), Chryssoulis (1990), and AREHART et al. (1993a) indicate that $\mathrm{Au}$ is a constituent of a solid solution in arsenian pyrite. Gold and As were deposited in arsenian pyrite overgrowths on preexisting pyrite (and perhaps other mineral?) surfaces as a function of redox reactions involving oxidation of $\mathrm{Au}$ and reduction of As.

\section{GEOLOGY OF THE POST/BETZE DEPOSIT}

The present study focused on the Post/Betze deposit, the largest SHDG deposit discovered to date, with published ore reserves in excess of 25 million ounces of Au. Post/Betze and most other major SHDG deposits are located in northcentral Nevada (Fig. 1). Ore at Post/Betze occurs in both sedimentary and igneous rocks, over a vertical distance of at least $750 \mathrm{~m}$. Much of the orebody is primary sulfide ore and has not been subjected to any surficial weathering effects. Figure 2 is a simplified geological map and cross-section of the main ore zones at Post / Betze. The geology and geochronology of this deposit were described by BETTLES (1989) and AREHART et al. (1993b) and are summarized briefly here.

The major ore host at Post/Betze is the upper $200 \mathrm{~m}$ of the Silurian/Devonian Roberts Mountains Formation; the top of this section is locally termed the Popovich Formation (EVANS, 1980). The Roberts Mountains Formation comprises interbedded thin- to thick-bedded silty to sandy carbonates with minor massive limestone units. In the unaltered rock, the detrital component is largely quartz, with minor

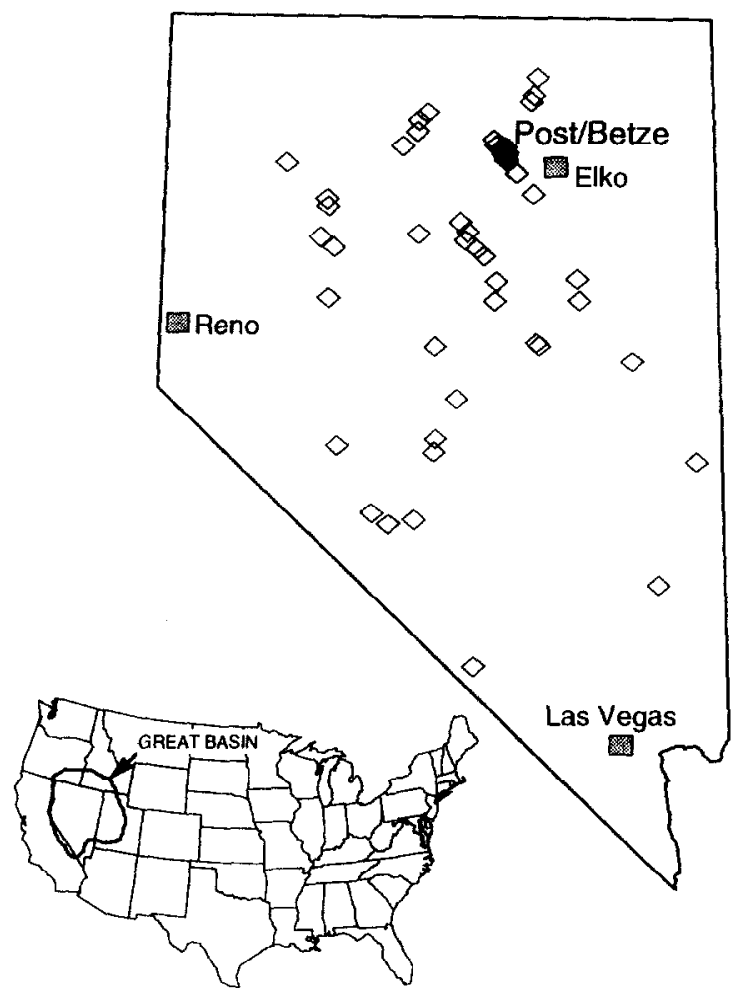

FIG. 1. Location map showing major sediment-hosted disseminated gold deposits of Nevada. Post/Betze is the black diamond northwest of Elko.

amounts of feldspar, muscovite, and clays. The same unit hosts the deposit at Carlin, which is located $15 \mathrm{~km}$ to the southeast and which has been described in detail by RADTKE (1985). Lesser amounts of ore also are present in the Rodeo Creek Formation and intrusive rocks of the Goldstrike stock and associated dikes and sills. The unaltered Goldstrike stock and associated dikes comprise quartz monzonitic to granitic equigranular intrusive rocks and were emplaced at $157 \mathrm{Ma}$, significantly prior to gold mineralization, which took place at approximately $117 \mathrm{Ma}$ (AREHART et al., 1993b).

Alteration within the sedimentary rocks at Post/Betze is similar to that of other sediment-hosted disseminated gold deposits and comprises decarbonatization, silicification, and argillization (RADTKE, 1985; BAKKEN and EINAUDI, 1986; KUEHN, 1989; IlCHIK, 1990; AREHART et al., 1993b). Decarbonization was the earliest alteration at Post/Betze and has affected nearly all of the sedimentary rocks in the vicinity of the orebody to varying degrees. This was followed by silicification along faults and fractures and more permeable stratigraphic horizons. The latest alteration, intense argillization, is confined largely to major faults and rocks immediately adjacent to those structures. The majority of the ore is present in decarbonatized and weakly to moderately silicified rocks. Although some ore-grade material is present in intensely silicified rocks, the association between intense silicification and $\mathrm{Au}$ is not as well developed as at other deposits, such as Carlin (BAKKEN and EINAUDI, 1986) and Jerritt Canyon (Hofstra et al., 1988). 
(a)

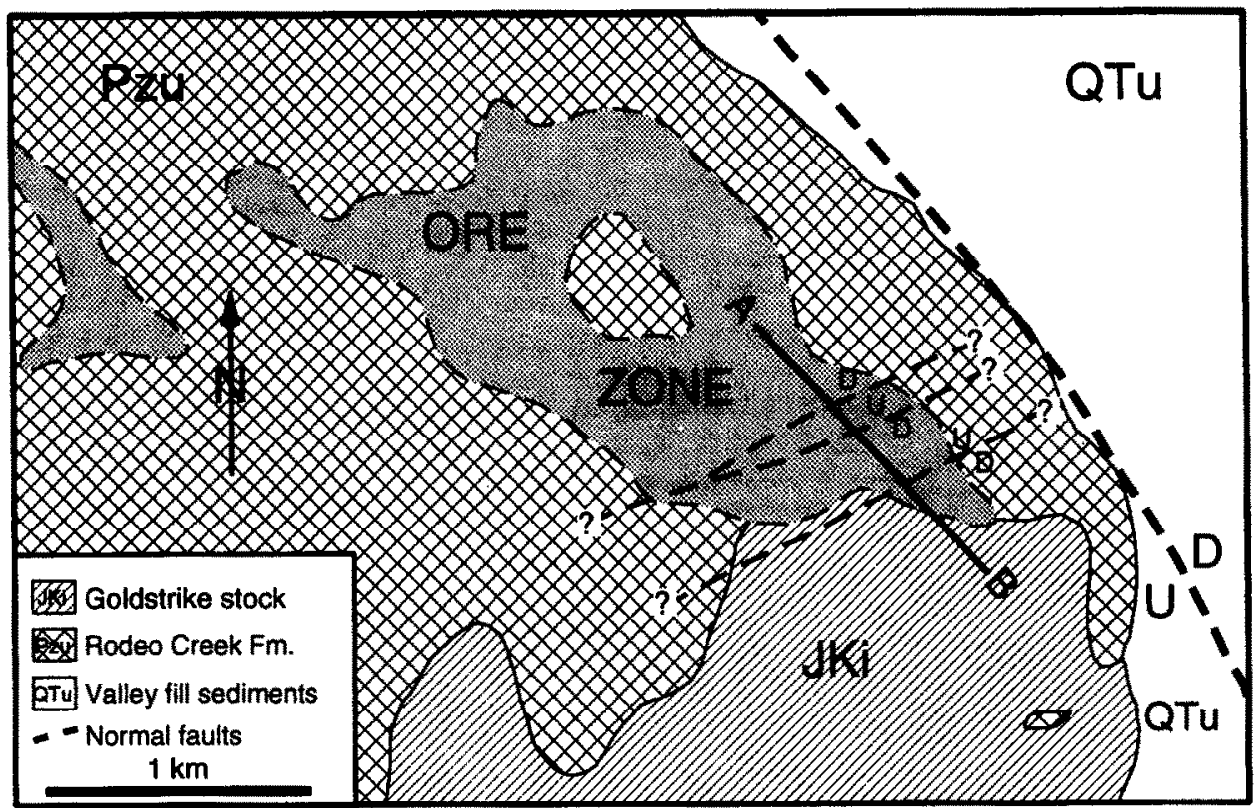

(b)

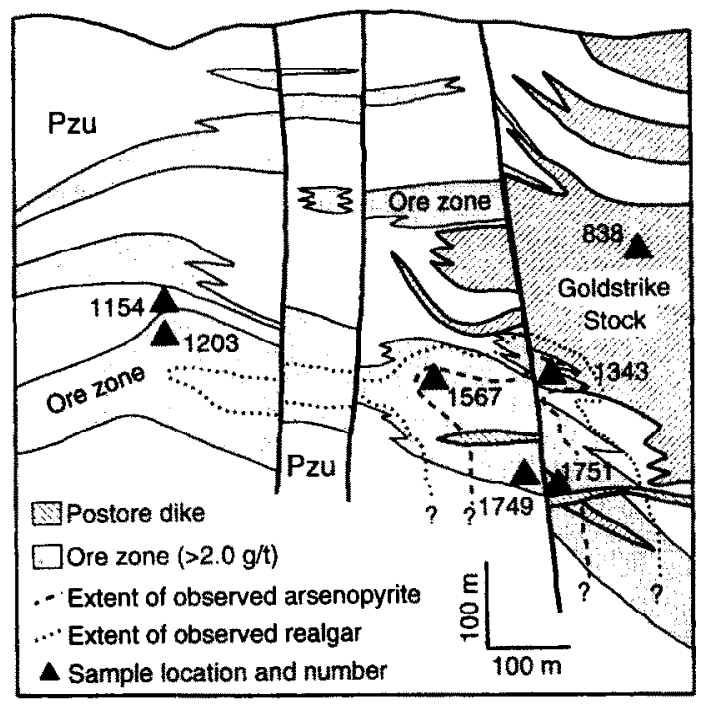

FiG. 2. (a) Simplified geological surface map of the Post/Betze deposit. (b) Simplifed geological cross-section of the Post/Betze deposit. Sample locations described in the text are shown as triangles.

Arsenic minerals at Post/Betze are associated closely in space and probably in time with gold mineralization; the most commonly observed minerals include arsenopyrite, realgar, and orpiment (Figs. 3 and 4). Arsenopyrite was the earliest of these minerals to precipitate and was followed by rare native As. Native As has been reported only infrequently at several SHDG deposits, possibly because of the difficulty in recognizing it in heavily carbonaceous ores (RYTUBA, 1985). Most of the ore-stage pyrite appears to be As-rich. This may explain the paucity of observed native As in the deposit as it is incorporated into pyrite, perhaps as submicronsized native As grains (JORALEMON, 1951; WELLS and MUL-
LENS, 1973; RADTKE, 1985) or stoichiometrically (as a metastable phase; FLEET et al., 1988). Realgar and orpiment are most common in veins late in the paragenetic scquence and probably were deposited during waning stages of mainstage hydrothermal activity. A second generation of Au-poor arsenian pyrite is very late in the paragenetic sequence and occurs as breccia cement and vug fillings.

This paragenetic sequence is also reflected in the gross aspects of As mineral zoning, from arsenopyrite in the core of the system, outward to realgar/orpiment (Fig. 2b). Goldbearing arsenian pyrite is present throughout the ore zone; its presence is most easily recognized in higher-grade parts 


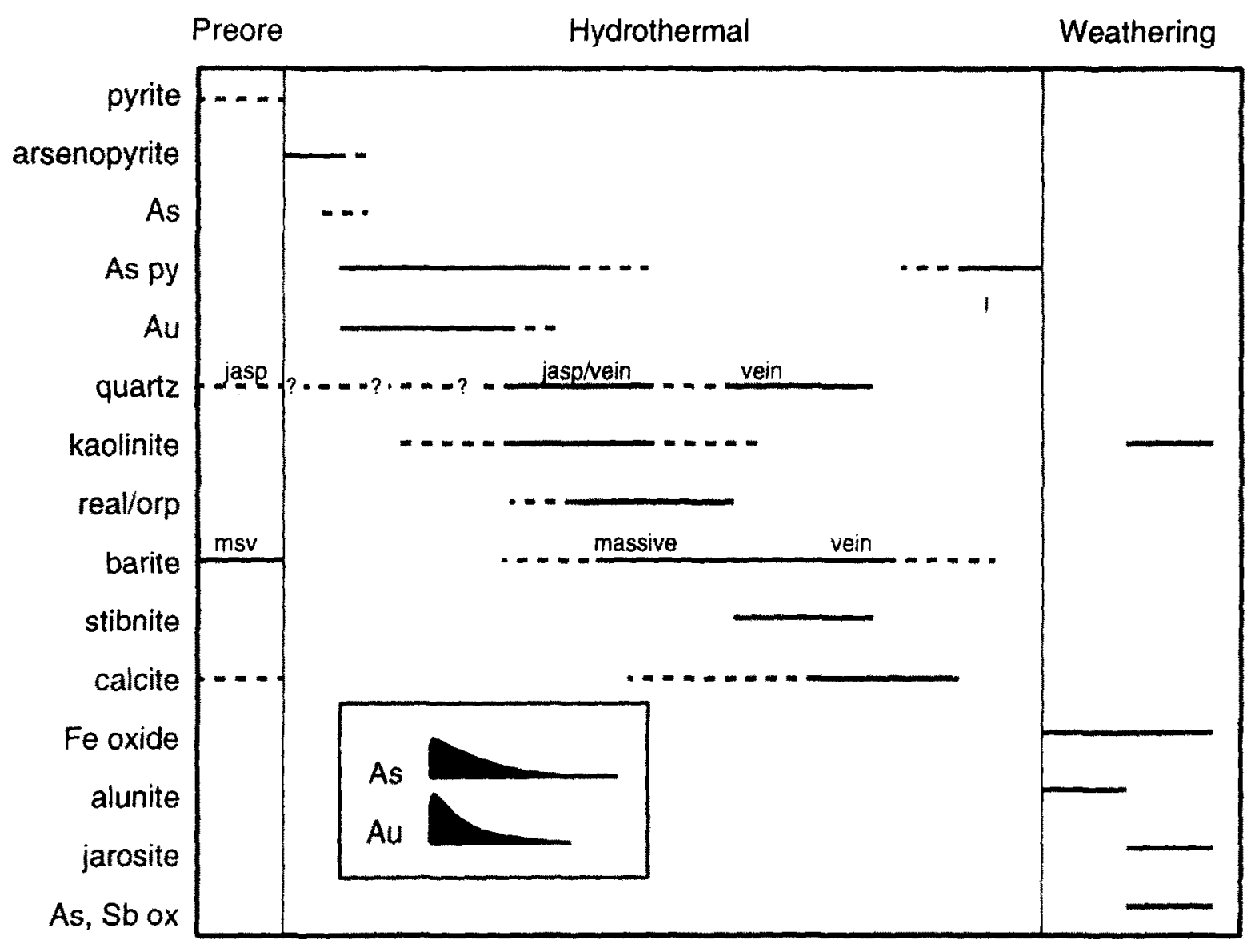

\section{Paragenesis, Post/Betze Deposit}

FIG. 3. Paragenetic sequence diagram for the Post/Betze deposit. Inset is a generalized representation of the relative amount of $A$ s and $A U$ deposited in ore-stage pyrite through time.
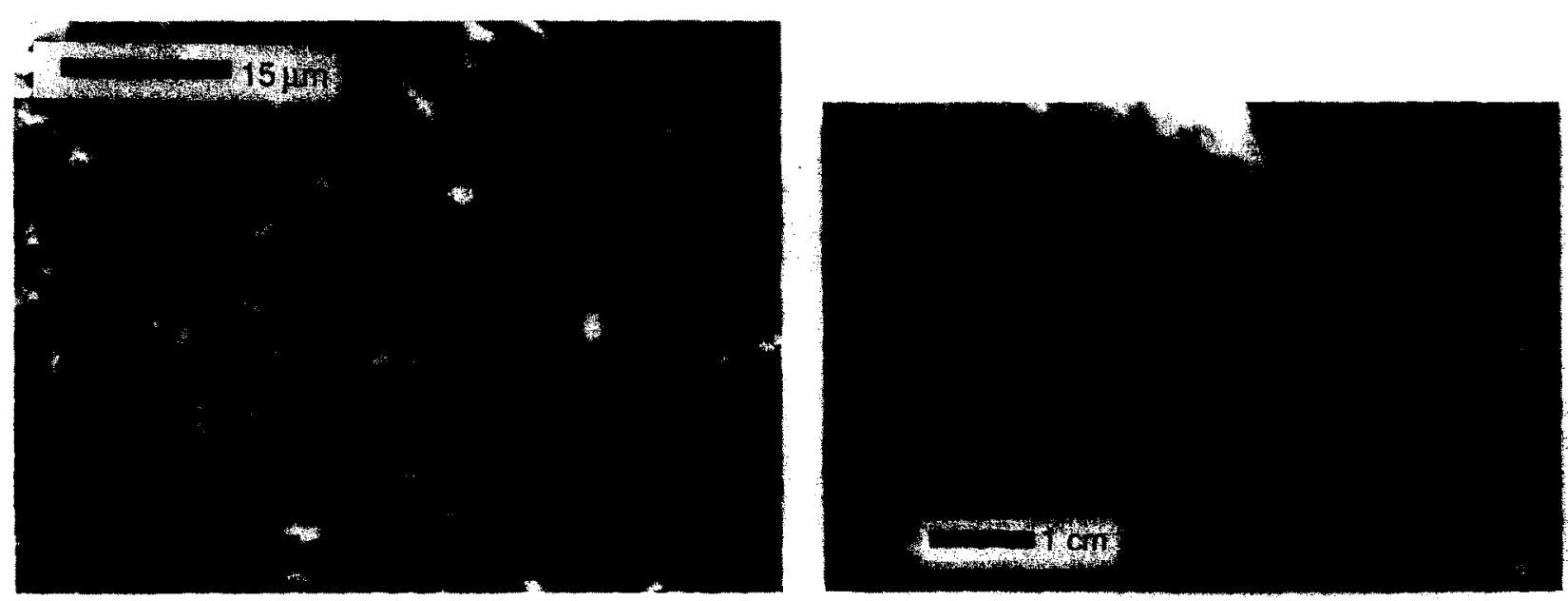

FIG. 4. Photographs illustrating critical features of the As mineral paragenetic sequence. (a) Backscattered electron image of an aggregate of preore pyrite grains (medium grey) overgrown first by arsenopyrite (white spots) and then by arsenian pyrite (zoned grey shades). Black material surrounding aggregates is silicate matrix. (b) Hand specimen of a latc-stage rcalgar-calcitc vein ( white = calcite; light grey = rcalgar) cutting arsenian pyrite-bearing ore. Vein is significantly lower grade than wallrock. 
Table 1. $\mathrm{Au}, \mathrm{As}$, and $\delta^{34} \mathrm{~S}$ determinations from Post/Betze samples.

\begin{tabular}{|c|c|c|c|c|c|}
\hline Sample \# & ppm Au & \%AS & $\delta^{34} \mathrm{SCDT}$ & phase & Paragenesis \\
\hline $838-A$ & & & 4 & po & Preore igneous po \\
\hline $838-B$ & & & 6 & po & Preore igneous po \\
\hline 838-C & & & 12 & mc & Replacing po \\
\hline 838-D & & & 11 & $\mathbf{m c}$ & Replacing po \\
\hline 838-E & & & 8 & py & Crosscutting latest vein \\
\hline $\begin{array}{l}\text { 838-F } \\
\text { 838-G }\end{array}$ & & & $\begin{array}{r}9 \\
10\end{array}$ & $\begin{array}{l}\text { py } \\
\text { py }\end{array}$ & $\begin{array}{l}\text { Crosscutting latest vein } \\
\text { Replacing po }\end{array}$ \\
\hline 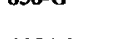 & & & & & кepracong po \\
\hline $1154-1$ & 2.3 & .17 & & $p y$ & Cube 1 , rastered in center of cube \\
\hline $1154-15 C$ & 0.58 & .02 & & py & Cube l, near edge \\
\hline $\begin{array}{l}1154-16 C \\
1154-13\end{array}$ & 0.28 & .03 & & py & Cube I, near edge \\
\hline $\begin{array}{l}1154-13 \\
1154-A\end{array}$ & 0.10 & .01 & & py & Cube II, As-free area \\
\hline IIS4-A & & & -4 & $n y$ & Cube I. preore py cube \\
\hline $\begin{array}{l}1 / 54-G \\
I I 54-I\end{array}$ & & & -6 & $p y$ & Cube I. preore py cube \\
\hline $\begin{array}{l}1154-I \\
1154-F\end{array}$ & & & -4 & $p y$ & Cube I, preore py cube \\
\hline $\begin{array}{l}1154-F \\
1154-J\end{array}$ & & & -6 & $p y$ & Near Cube I, preore py in quartz \\
\hline $\begin{array}{l}1154-J \\
1154-K\end{array}$ & & & -1 & py & Cube II, unaltered preore py \\
\hline $\begin{array}{l}1154-K \\
1154-L\end{array}$ & & & -2 & py & Cube II, unaltered preore py \\
\hline $\begin{array}{l}1154-L \\
1154-N\end{array}$ & & & -6 & $p y$ & Cube $I I$, in crater from $\# I 3$ \\
\hline $\begin{array}{l}1154-N \\
1154-P\end{array}$ & & & -2 & $p$ & Cube $I I$, on side of crater from $\# 12$ \\
\hline $\begin{array}{l}1154-P \\
1154-R\end{array}$ & & & -3 & py & Cube II, unaltered preore py \\
\hline $\begin{array}{l}1154-R \\
1154-S\end{array}$ & & & 0 & $p y$ & Cube II, near rim of unaliered $p y$ \\
\hline $\begin{array}{l}1154-S \\
1154-U\end{array}$ & & & 0 & py & Cube II, unaltered preore py \\
\hline $\begin{array}{l}1154-U \\
1154-9\end{array}$ & & & -4 & py & Cube II. on rim of unattered py \\
\hline $\begin{array}{l}1154-9 \\
1154-11\end{array}$ & 11.0 & .77 & & aspy & Center Cube I, As-rich "spots" \\
\hline $\begin{array}{l}1154-11 \\
1154-15 B\end{array}$ & 37.0 & 4.8 & & aspy & Oblique fracture w/ As replacement \\
\hline $\begin{array}{l}1154-15 B \\
1154-16 B\end{array}$ & 2.0 & 1.8 & & aspy & Cube I, overlapping cube margin \\
\hline $\begin{array}{l}1154-16 B \\
1154-12\end{array}$ & 2.0 & 1.4 & & aspy & Cube I, overlapping cube margin \\
\hline $\begin{array}{l}1154-12 \\
1154-M\end{array}$ & 76.0 & & & aspy & Cube II, As-rich fractures \\
\hline $\begin{array}{l}\text { 1154-M } \\
1154-W\end{array}$ & & & $\begin{array}{l}12 \\
11\end{array}$ & $\begin{array}{l}\text { aspy/py } \\
\text { aspy/py }\end{array}$ & Cube II, adjacent to \#12 \\
\hline $1154-Q$ & & & 4 & $\begin{array}{l}\text { aspy/py } \\
\text { aspy/py }\end{array}$ & \\
\hline $1154-\mathrm{T}$ & & & 2 & aspy/py & Cube II, includes As-rich fracture \\
\hline $1154-10$ & 0.12 & 1.5 & & aspy & Cube I, oldest major overgrowth band \\
\hline $1154-15 \mathrm{~A}$ & 0.37 & 1.4 & & aspy & Cube 1 , oldest major overgrowth band \\
\hline $1154-16 \mathrm{~A}$ & 0.27 & 1.4 & & aspy & Cube I, oldest major overgrowth band \\
\hline $1154-B$ & & & -28 & aspy & Cube 1 , oldest major overgrowth band \\
\hline $1154-I$ & & & -29 & aspy & Cube 1 , oldest major overgrowth band \\
\hline $1154-3$ & 0.08 & 1.7 & & aspy & Cube I, second overgrowth band \\
\hline $1154-8$ & 0.08 & 2.0 & & aspy & Cube I, second overgrowth band \\
\hline $1154-14$ & 0.11 & 2.0 & & aspy & Cube ll, second overgrowth band \\
\hline $1154-\mathrm{C}$ & & & -16 & aspy & Cube I, second overgrowth band \\
\hline I154-D & & & -17 & aspy & Cube $\mathrm{I}$, second overgrowth band \\
\hline $1154-\mathrm{V}$ & & & -25 & aspy & Cube II, oldest overgrowth band \\
\hline $1154-5$ & 0.13 & 1.6 & & aspy & Cube $I$, youngest overgrowth band \\
\hline $1154-\mathrm{F}$ & & & -12 & aspy & Cube $I$, youngest overgrowth band \\
\hline $1203 \cdot I$ & 77.0 & 1.9 & & $m$ & Core of py aggregate \\
\hline $1203-3$ & 83.0 & 1.6 & & $p y$ & Core of py aggregate \\
\hline $1203-2$ & 116.0 & 3.4 & & aspy & As-rich rims on py aggregate \\
\hline $1203-4$ & 265.0 & 1.4 & & aspy & As-rich rims on py aggregate \\
\hline $1343-A$ & & & 2 & $p y$ & Fine grained py clot \\
\hline $1343-B$ & & & 0 & py & Fine grained py clot \\
\hline 1343.C & & & 18 & apy & Isolated euhedral crystal \\
\hline 1343-D & & & 18 & apy & Isolated euhedral crystal \\
\hline 1343-E & & & 18 & apy & Isolated euhedral crystal \\
\hline 1343-F & & & 14 & apy/py & Group of crystals \\
\hline 1343-G & & & 17 & apy & Isolated euhedral crystal \\
\hline $1567-6$ & 58.0 & 1.5 & & aspy/py & Preore core + overgrowth \\
\hline 1567.7 & 94.0 & 1.9 & & $a s p y / p y$ & Preore core + overgrowth \\
\hline $1567-8$ & 70.0 & 2.2 & & aspv/py & Preore core + overgrowth \\
\hline $1567-9$ & 385. & 3.8 & & aspy & Early overgrowth + some core \\
\hline $1567-2$ & 690. & 3.8 & & aspy & Mostly carly overgrowth \\
\hline $1567-4$ & 570. & 4.0 & & aspy & Mostly early overgrowth \\
\hline $1567-5$ & 470. & 4.4 & & aspy & Early + late overgrowth \\
\hline $1567-1$ & 220. & 2.0 & & uspy & Early + late overgrowth \\
\hline $1567-3$ & 290. & 2.8 & & aspy & Mostly late overgrowth \\
\hline $1567-A$ & & & 16 & aspy/py & Mix of core pyrite + overgrowth \\
\hline $1567-\mathrm{C}$ & & & 14 & aspy/py & Mix of core pyrite + overgrowth \\
\hline 1567-B & & & 20 & dspy & Overgrowth pyrite near rim \\
\hline 1567-D & & & 15 & aspy & Overgrowth pyrite near rim \\
\hline 1749-A & & & 5 & py & Cluster of small preore (?) crystals \\
\hline $1749-B$ & & & 5 & py & Second cluster of preore (?) crystals \\
\hline 1749-C & & & 19 & apy & Group of euhedral crystals \\
\hline 1749-D & & & 23 & apy & Second group of euhedral crystals \\
\hline $1751-1$ & 0.44 & .16 & & py & Preore igneous pyrite \\
\hline $\begin{array}{l}1751-A \\
1751-5\end{array}$ & 31.0 & 3.8 & 9 & $\begin{array}{c}\text { py } \\
\text { asmc }\end{array}$ & $\begin{array}{l}\text { Preore igneous pyrite } \\
\text { Vein margin me + preore py }\end{array}$ \\
\hline $1751-6$ & 32.0 & 5.4 & & asme & $\begin{array}{l}\text { Vein margin me + preore py } \\
\text { Vein }\end{array}$ \\
\hline $1751-10$ & 13.0 & (12.) & & asmc & Vein me $90 \mu \mathrm{m}$ from vein wall \\
\hline $1751-9$ & 5.6 & (13.) & & asme & Vein me $140 \mu \mathrm{m}$ from vein wall \\
\hline $1751-8$ & 4.0 & (11.) & & asmc & Vein me $150 \mathrm{\mu m}$ from vein wall \\
\hline 1751.7 & 2.5 & (10.) & & Asme & Vein me $350 \mathrm{\mu m}$ from vein wall \\
\hline 1751-B & & & 17 & asmc & Vein me 70 mm from vein wall \\
\hline 1751-C & & & 16 & asmc & Vein $\mathrm{mc} 80 \mathrm{\mu m}$ from vein wall \\
\hline 1751-D & & & 20 & asme & Vein me $750 \mu \mathrm{m}$ from vein wall \\
\hline
\end{tabular}

*Mineral abbreviations: $\mathrm{py}=$ pyrite, $\mathrm{po}=$ pyrrhotite, $\mathrm{mc}=$ marcasite, apy $=$ arsenopyrite, aspy $=$ arsenian pyrite, asmc $=$ arsenian marcasite. Samples in italics are preore minerals, those in bold are ore-stage minerals, and those in normal type are postore minerals. Parenthetical As values are above calibration limits. Conventional fire assays for the $1.5-\mathrm{m}$ intervals containing these samples is as follows: $838=0.2$ ppm: $1154=1.4 \mathrm{ppm} ; 1203=37.2 \mathrm{ppm} ; 1343-32.0 \mathrm{ppm} ; 1567=5.8 \mathrm{ppm} ; 1749=8.2 \mathrm{ppm} ; 1751=56.5 \mathrm{ppm}$. 
Table 2. $\delta^{34} \mathrm{~S}$ values for conventional analyses of Post/Betze pyrites relative to Cañon Diablo troilite. Uncertainties for all analyses $= \pm 0.3 \%$ ( $2 \sigma)$.

\begin{tabular}{lclr} 
& & & \\
Sample No. & Mineral & Comments & $\delta^{34} S$ \\
\hline ST7/975 & py & Fresh Goldstrike stock & 7.2 \\
$214 / 1782$ & py & Fracture coating in stock & -1.0 \\
$214 / 1409$ & py & Higrade altered Goldstrike stock & 5.6 \\
$214 / 1412$ & py & Higrade altered Goldstrike stock & 6.2 \\
PVS-3 & py & Milky quartz-py vein cutting stock & 6.4 \\
$241 / 1783$ & py & Disseminated in altered stock & 6.2 \\
$118 / 1609$ & py & Altered preore dike & 3.9 \\
$252 / 1368$ & py & Higrade altered Goldstrike stock & 5.3 \\
$3 / 1154$ & & & \\
$3 / 1719$ & py & Breccia with sulfide cement & 23.6 \\
$118 / 1230$ & py & Disseminated in decarbonized sediments & 3.7 \\
BP-79 & py & Disseminated in sediments & 1.0 \\
& py & Carbonaceous sediments from pit & 9.4 \\
\hline
\end{tabular}

of the ore. Because of the apparent irregularities in the geometries of breccia bodies and limited exposures (essentially only core or chips are available), their spatial distribution is poorly known.

In all of the samples described here, Au has been documented within As-rich iron sulfide, though not all As-rich sulfides contain Au. Other As-bearing sulfides (arsenopyrite, realgar, orpiment) from this and other similar deposits conLain anomalous, but lesser, amounts of Au (S. L. Chryssoulis, unpubl. data). Textural relations in the ore samples studied indicate that all of these early phases were deposited preferentially where pyrite already was present and formed a substrate for further deposition of iron sulfide. Most Au was deposited early in the precipitation of arsenian pyrite, but gold deposition continued throughout the early part of the paragenetic sequence (Fig. 3 ).

\section{ANALYTICAL MATERIALS AND METHODS}

Most of the discussion in the literature regarding the location and nature of the Au in SHDG deposits has been focussed on micrometer to submicrometer-sized Au particles that have been observed by optical, SEM, and high-resolution TEM methods (e.g., HAUSEN and KeRR, 1968; RADTKE, 1985; HAUSEN and PARK, 1985; HOFSTRA et al., 1988; BAKKEN et al., 1989). Although such grains exist, our observations indicate that they probably are not the major form of $\mathrm{Au}$ in these deposits but rather the only ones recognizable with the lechniques used. Due to the large volume of excitation, analyses by X-ray Synchrotron radiation (CHAO et al., 1986) do not differentiate colloidal-size Au from Au dispersed in the sulfide crystal structure. In contrast to these techniques, quantitative analysis of pyrite for $\mathrm{Au}$ by ion microprobe comprises numerous individual analyses which are then averaged to obtain a final value for the Au concentration at any given spot. The spots analyzed in this and previous studies (AREHART et al., 1993a), which had a depth sampling resolution of 100 $\AA$, failed to reveal the presence of Au coarser than $\sim 50 \AA$ (details of these calculations are described by CHRYSSOULIS et al., 1987) in iron sulfide samples having Au concentrations as high as $690 \mathrm{ppm}$. It is inferred that $\mathrm{Au}$ is present predominantly as particles fincr than $100 \AA$ in diameter and/or in solid solution in these mineral phases.

Elemental distribution and concentration data provide a framework for sulfur isotope analyses reported in this paper. Approximately twenty-five samples of unweathered preore rock and ore (ranging in $\mathrm{Au}$ content from 100-150 ppm) were examined by reflected and transmitted light microscopy and scanning electron microscopy. These samples were also analyzed for both Au concentration and sulfur isotope composition by conventional methods to guide our selection of samples for detailed analyses. From this preliminary study, seven samples (Fig. 2b) were selected for ion microprobe study. These samples were chosen to represent the range of mineralogy, gold concentrations, and isotopic compositions observed in the deposit.

Four of the seven samples are from altered igneous rocks in or adjacent to the main ore zone; seven Au determinations and twentytwo sulfur isotope analyses were made of these samples. Two of these four ( 1343 and 1751) are from intensely altered and mineralized rock of the Goldstrike stock; one sample (1749) is from an altered preore dike closely associated with the Goldstrike stock. The fourth igneous sample (838) is from very weakly altered, preore Goldstrike stock. Three other samples are from altered and mineralized sedimentary rocks; thirty-two Au determinations and twenty-six sulfur isotope measurements were made on these samples. Samples 1203 and 1567 are from the main ore zone, and 1154 is from subore grade material immediately above the main ore zone. Both samples 1154 and 1203 are breccias with pyrite cement. Several grains from each of these seven samples were analyzed by ion probe methods. Secondary ion mass spectrometry was employed in imaging mode to delineate the elemental ( $\mathrm{Au}$ and $\mathrm{As}$ ) zoning patterns in these sulfides, and spot measurements wcre used to quantify Au and As concentrations and sulfur isotope compositions. For many of these grains, elemental measurements were paired with isotopic measurements.

Gold and As were analyzed at the University of Western Ontario with a Cameca IMS-3f ion microprobe; details of the quantitative analytical procedures and standardization are given by CHRYSSOULIS et al. $(1987,1989)$. $\mathrm{A} \mathrm{Cs}^{+}$primary beam was used for determination of Au by negative secondary ions. External standardization by means of mineral-specific calibration curves was used to quantify results. The standard used was produced by ion implantation; the analytical precision using this approach is of the order of $20 \%$ at the $1 \mathrm{ppm}$ level (CHRYSSOuLIS et al.. 1989). Quantification of As content of spots was done by analyses of standards along with the unknowns; As content of standards has been previously calibrated by electron microprobe analyses. The spot size for quantitative analyses is approximately $35 \mu \mathrm{m}$ in diameter, although the ablation pit is larger.

Bulk sulfur isotope analyses of pyrite were made utilizing a modification of the $\mathrm{Cu}_{2} \mathrm{O}$ extraction technique of ROBINSON and $\mathrm{KU}$ $\mathrm{SAKABE}$ (1975); isotopic ratios of $\mathrm{SO}_{2}$ were measured on a VG-602 mass spectrometer in the University of Michigan Stable Isotope Laboratory. Analytical uncertainties in reported $\delta^{34} \mathrm{~S}$ values for standard data are $\pm 0.3 \%$ o $(2 \sigma)$.

In situ sulfur isotope analyses were performed in three sessions with spot sizes of approximately 25,15 , and $25 \mu \mathrm{m}$, respectively, on the Sensitive High Resolution Ion MicroProbe (SHRIMP I) at the Australian National University. Techniques and the pyrite standard used are described in ELDRIDGE et al. $(1987,1989)$. The standard marcasite used for correction of data for the Post/Betze marcasite has a conventionally determined $\delta^{34} \mathrm{~S}$ value of $-2.1 \%$, and the $\delta^{34} \mathrm{~S}$ value of standard arsenopyrite is $3.4 \%$. Though these standards were used for the appropriate target matrices, it has been found that the analytical fractionation for marcasite, arsenopyrite, and pyrite is indistinguishable within analytical uncertainties. These analytical uncertainties, due largely to counting statistics, for pyrite and marcasite are $\pm 2 \%(2 \sigma)$, while those for arsenopyrite are larger $( \pm 3 \%)$ because of the lower concentration of sulfur. 


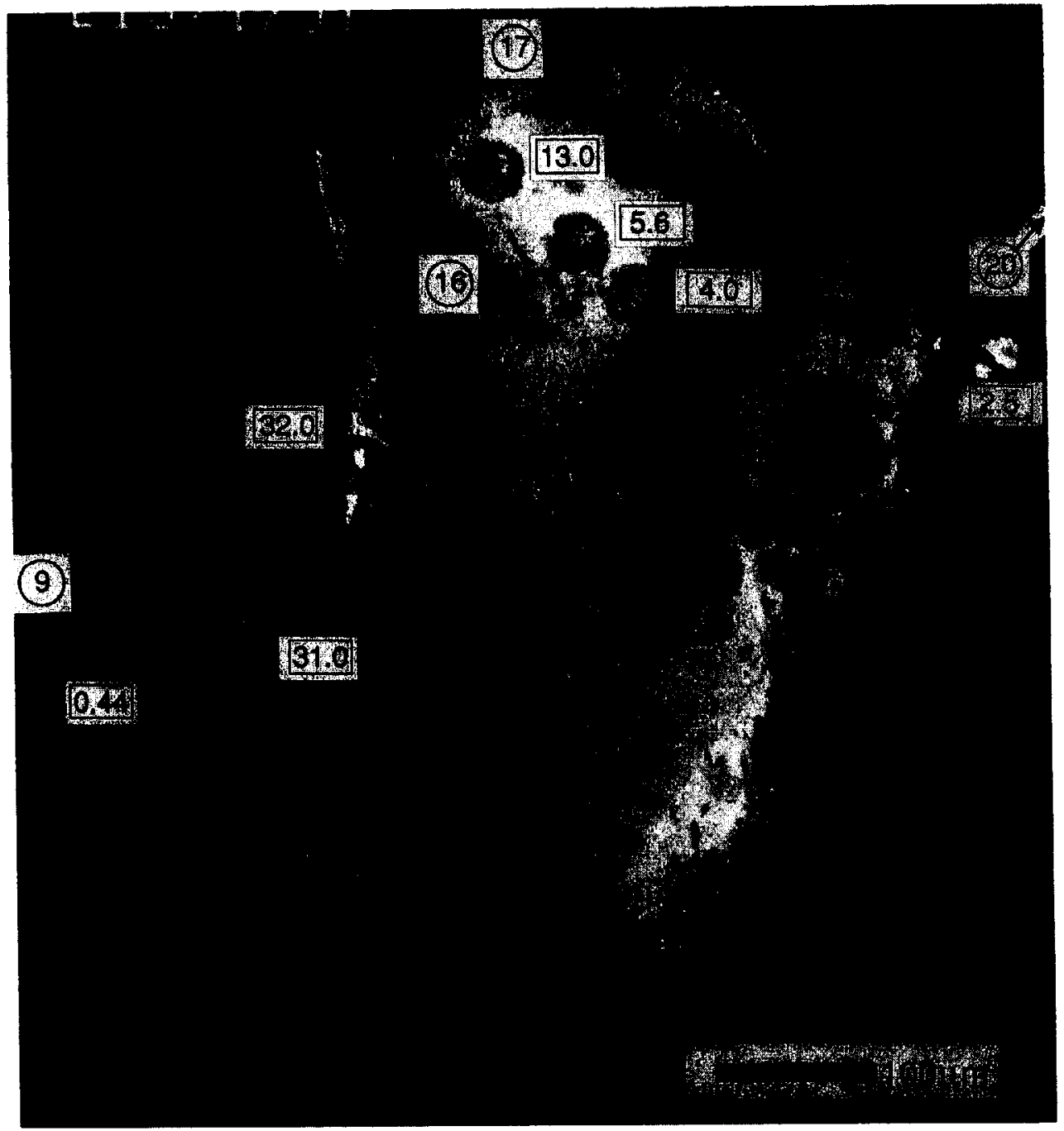

FiG. 5. Backscattered electron photomicrograph of sample 1751. This view includes approximately one-quarter of the vein width. The lighter-shaded rectangular area in the center of the photograph is where the carbon coating has been burned off the sample during ion probe analysis. Analytical spots are visible as pits in the sample: sulfur isotope analyses are indicated by the solid circles and values in round spots; gold/arsenic analyses by the dashed circles; gold values (in ppm) in the rectangular spots. The sulfur isotope analysis ( $20 \%$ ) shown on the right side of the photograph was taken from the center of the vein, out of the field of view by $500 \mu \mathrm{m}$. Black areas are quartz or other silicates. The large area of intermediate to dark grey in the left side of the field of view is preore, igneous pyrite from the Goldstrike stock. Lighter areas in the center and right side of the photograph are arsenic-bearing vein marcasite; the microscope has been adjusted to maximize the contrast in average atomic number (in this sample primarily a function of As content) of the iron sulfides.

Scanning electron microscopy and photomicrography were done in the University of Michigan Electron Microbeam Analysis Laboratory utilizing a Hitachi S-570 scanning electron microscope in backscattered electron and secondary electron modes. Beam currents ranged from 1-10 nA; acceleration voltages were $15-20 \mathrm{keV}$.

\section{ANALYTICAL RESULTS}

Ion probe analyses of sulfur isotopes, and Au and As concentrations of samples whose locations are shown in Fig. 2b are presented in Table 1 in per mil relative to Cañon Diablo troilite, parts per million, and percent, respectively. Conventional sulfur isotope analyses are presented in Table 2 in per mil relative to Cañon Diablo troilite. Data in Table 1 are grouped by sample and sequence in the paragenesis and keyed to photomicrographs in Figs. 5-10. Analytical spots are visible as pits in the samples: sulfur isotope analyses are indicated by the solid circles and values in round spots; $\mathrm{Au} / \mathrm{As}$ analyses by the dashed circles and Au values (in ppm) in the rectangular spots. In most cases, the mineral species discussed is known; however, arsenian pyrite may easily be misidentified as marcasite in reflected light, as the bireflectance of arsenian pyrite is similar to that of marcasite. X-ray diffraction of several samples of this type showed that no marcasite was present in the samples. Where a distinction between pyrite and marcasite was not made, the mineral or mixture is referred to as "iron sulfide." 


\section{Igneous-hosted Samples}

Sample 1751 is from a high-grade ore zone in altered Goldstrike stock. Vein material and adjacent wall rock pyrite have distinctly different As and Au contents (Fig. 5; Table 1). Wall rock pyrite, probably of deuteric origin, is essentially devoid of Au and As; whereas the vein contains As-bearing marcasite with significant $A u$ values. Gold values are highest in the first few micrometers adjacent to the wall rock pyrite ( $32 \mathrm{ppm}$ ) and decrease rapidly toward the center of the vein $(2.5 \mathrm{ppm})$. Note that, due to the spot size (Fig. 5), the vein margin analyses include a significant proportion of barren wall rock pyrite; therefore, the true gold content of the first few micrometers of vein material must be significantly higher than the reported value.

A similar sharp contrast between host rock and vein is observed in $\delta^{34} S$ values. Wall rock pyrite has a $\delta^{34} \mathrm{~S}$ value of $9 \%$, similar to $\delta^{34} \mathrm{~S}$ values of unaltered Goldstrike stock ( Tables 1 and 2). Vein material has $\delta^{34} \mathrm{~S}$ values between 16 and $20 \%$ ( Table 1). Although all of the sulfur isotope analyses of vein material overlap within analytical uncertainty, there is a suggestion of isotopic change from the margins of the vein to the core; two measurements near the vein margin are 16 and $17 \%$, whereas a measurement from the center of the vein is $20 \%$ (Fig. 5 ).

Two samples ( 1343 and 1749) of arsenopyrite- and pyritebearing igneous rock from the ore zone were analyzed by SHRIMP for their sulfur isotope compositions (Table 1). $\delta^{34} \mathrm{~S}$ values of arsenopyrite in both samples are between 17 and $23 \%$. Spot $1343 \mathrm{~F}$, which appears depleted in ${ }^{34} \mathrm{~S}$ relative to other samples, was shown after the analysis to be a mixture of pyrite and arsenopyrite. $\delta^{34} \mathrm{~S}$ values of pyrite from these same samples range from $0-5 \%$. The arsenopyrite values are virtually identical to those obtained from auriferous marcasite of sample 1751 (described above) and suggest a common source. $\delta^{34} \mathrm{~S}$ values of pyrite (Table 1 ) are similar to, though slightly lower than, those obtained for fresh Goldstrike stock using conventional techniques (Table 2).

A fourth sample (838; Fig. 6) contains pyrrhotite, which is interpreted to have formed during Goldstrike intrusion and which is therefore unrelated to Au mineralization. This pyrrhotite is cut and replaced by fine-grained marcasite-pyrite aggregates and finally cut by a pyrite microvein. Pyrrhotite has a $\delta^{34} \mathrm{~S}$ value of $4-6 \%$; the younger sulfides are enriched in ${ }^{34} \mathrm{~S}$ and have values of $8-10$ (pyrite) and 11-12 (marcasite).

\section{Sediment-hosted Samples}

Sample 1567 is from the main ore zone in the sedimentary section and is representative of the majority of the ore in sedimentary rocks. A composite cube from this sample is shown in Fig. 7. The core of the grain comprises probable preore diagenetic pyrite, which has been overgrown by arsenian pyrite containing abundant Au. Quantitative analysis of the individual spots from this sample yield Au concentrations in arsenian pyrite as high as $690 \mathrm{ppm}$ (Table 1). Sulfur isotope determinations were made on four spots in this crystal and range from 14-20\%o (Fig. 7; Table 1 ).

Figure 8 is a backscattered electron photomicrograph of

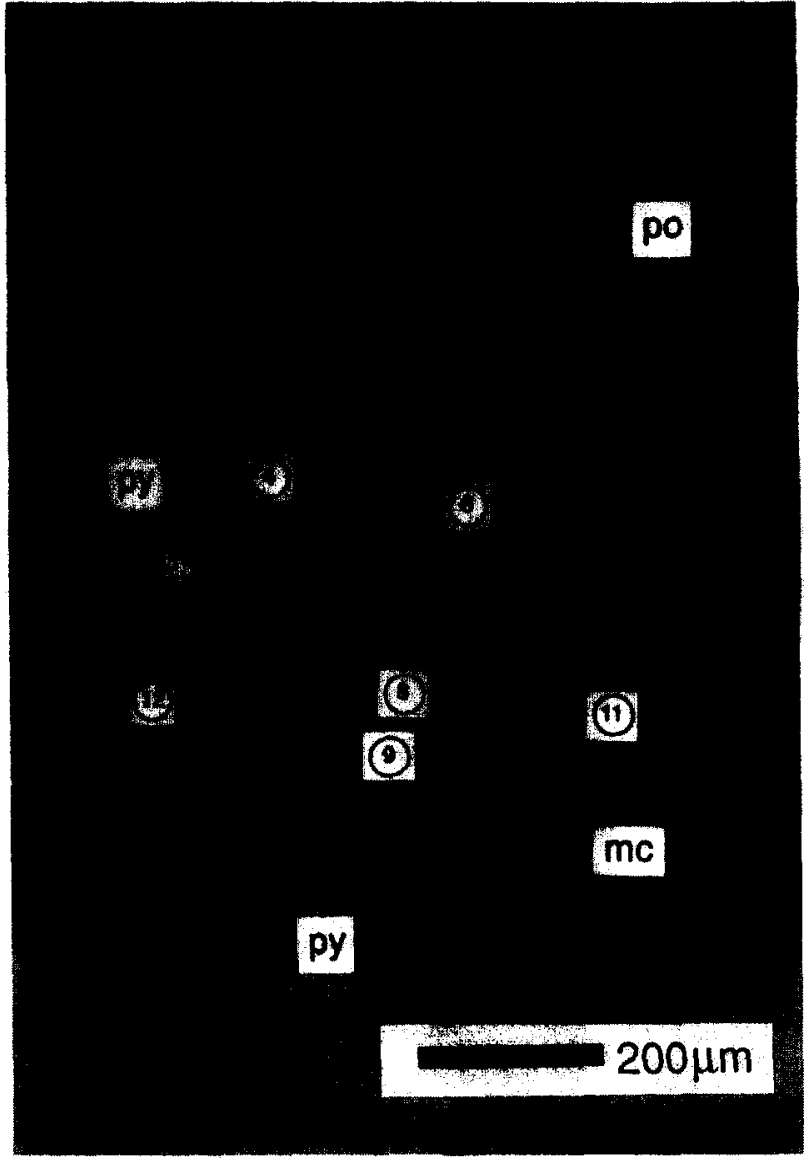

FIG. 6. Reflected light photograph of sample 838. Minerals are pyrrhotite (po), pyrite (py), and marcasite ( $\mathrm{mc}$ ). Sulfur isotope values are indicated by numbers in circles.

sample 1154, Cube I. In this sample, several generations of fine-grained arsenian pyrite overgrowths coat a breccia fragment which contains pyrite cubes. The pyrite cubes are preore and are of probable diagenetic origin. Gold concentrations in the cube are very low $(0.28-2.3 \mathrm{ppm})$. There is no significant $\mathrm{Au}$ associated with most of the overgrowth pyrite, as all $\mathrm{Au}$ values are below $0.5 \mathrm{ppm}$ (Table 1). However, Asrich pyrite adjacent to fractures in the cubes contains high concentrations of Au (11-76 ppm). Gold also is present in a thin (up to a maximum of $1 \mu \mathrm{m}$ in thickness), discontinuous band of As-rich iron sulfide that coats preore pyrite; this material locally is continuous with and, therefore is temporally equivalent to, the As-rich fracture filling.

Figure 9 is an enlargement of the margin of the pyrite cube of Fig. 8 showing Au distribution (Fig. 8a) and detailed analyses of the cube and oldest overgrowth material (Fig. 8b). The majority of the Au in this sample is contained in the thin band, as indicated by the map for mass 197 (Au). Detailed analyses of the gold content of this band and adjacent pyrite were made. Pyrite from immediately adjacent to, from either side of the band, and a volume which contained the band were analyzed separately for Au. By assuming that all $\mathrm{Au}$ in excess of the analyzed values adjacent to the band is contained in the band, a concentration of $31 \mathrm{ppm}$ is calculated 


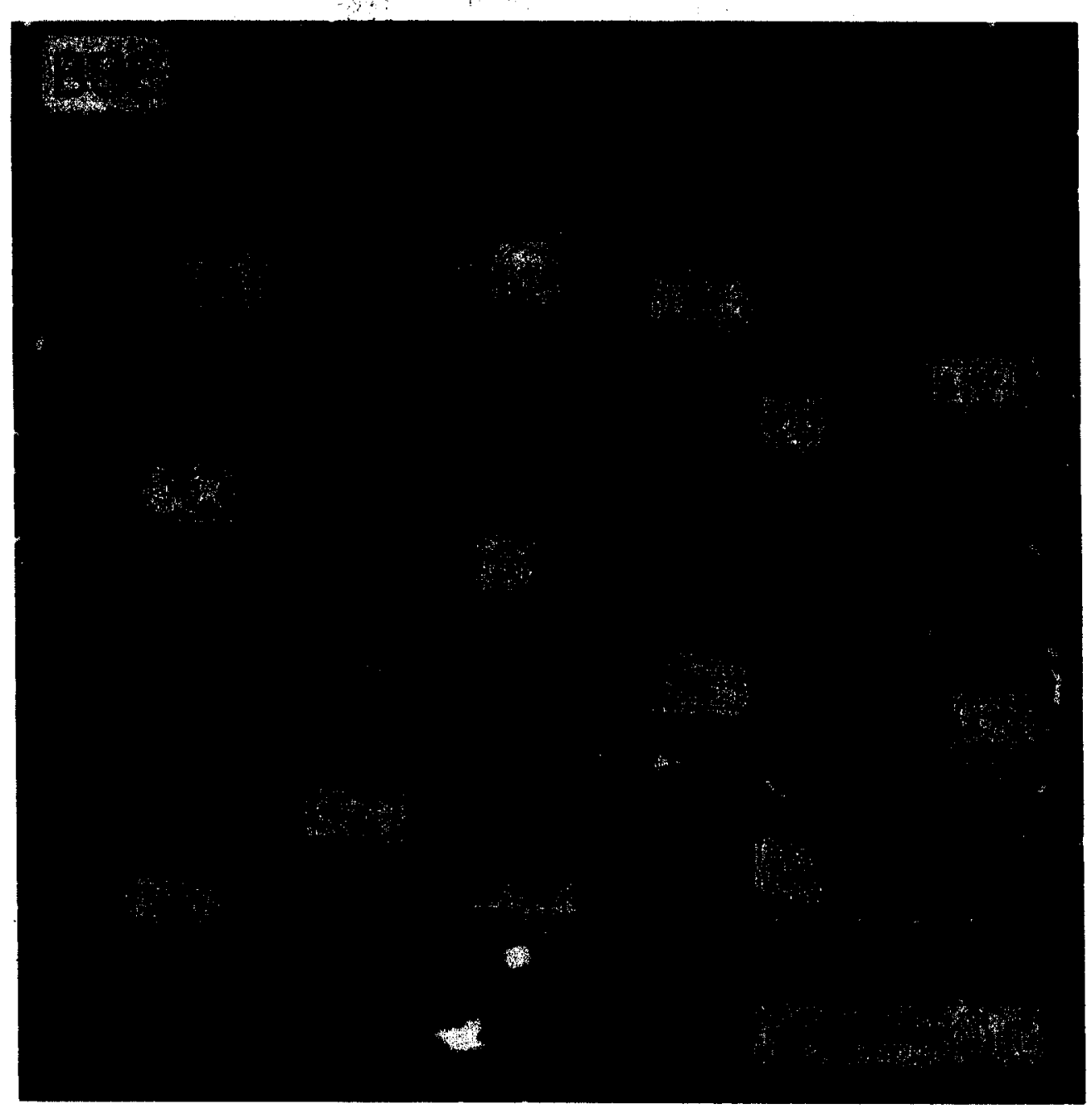

FIG. 7. Backscattered electron image of preore pyrite (sample 1567) overgrown by arsenian pyrite. Two small arsenopyrite grains (white) are visible in the bottom center of the photograph. Analytical symbols are the same as for Fig. 5. The core of this grain contains essentially no Au (the values shown include some of the overgrowth material because the analytical spot is larger than the preore grains), but the overgrowth pyrite is highly enriched in both arsenic and gold and has high $\delta^{34} \mathrm{~S}$ values.

for the thin band alone. This contrasts sharply with very low values $(<0.5 \mathrm{ppm})$ for the cubic pyrite and the younger arsenian overgrowth material on either side of the band.

Pyrite cubes in these breccia fragments appear to be diagenetic, based on their textures and habit and similarity to pyrite in unaltered Roberts Mountains Formation. These cubes have $\delta^{34} \mathrm{~S}$ values of -4 to $-6 \%$, values somewhat lower than those of most primary diagenetic sulfides from the Roberts Mountains Formation reported by RYE et al. (1978) or RADTKE et al. (1980). In sharp contrast to the pyrite cube, three major bands of overgrowth material have extremely low $\delta^{34} \mathrm{~S}$ values (Fig. 8). Growth from oldest bands to youngest bands progresses from values of -29 to $-12 \%$. Although these overgrowths also are notably As-rich and similar in habit to arsenian marcasite from sample 1751 , with the exception of the thin discontinuous band noted above, they contain no Au enrichments (Table 1). The sulfur isotope composition of the thin Au-bearing pyrite band precipitated on the rim of this cube has been difficult to measure accurately because of the radical shift in sulfur isotope compositions across the crystal boundaries.

A second cube from this sample has more prominent fractures with As enrichment along the margins of those fractures (Fig. 10). Arsenic-rich areas in fractures are also enriched greatly in Au over the preexisting cubic pyrite ( $76 \mathrm{ppm}$ vs. $0.10 \mathrm{ppm}$, respectively). Arsenian pyrite overgrowths are the same as those shown in Fig. 8 and contain essentially no Au. Spots which include As-enriched zones along fractures have $\delta^{34} \mathrm{~S}$ values slightly to moderatcly higher than As-free, preore cube material. These $\delta^{34} \mathrm{~S}$ values vary as a function of the proportions of As-free and As-enriched pyrite included in the analytical spot. The highest $\delta^{34} S$ values $(11-12 \%)$ are from immediately adjacent to a very Au-rich ( $76 \mathrm{ppm}$ ) intersection of fractures where the volume analyzed included predominantly As-enriched material. By estimation of the contribution of the preore cube vs. the fracture-marginal sulfur in a manner similar to that described above for $\mathrm{Au}$ analyses, the Au- and As-bearing zones have $\delta^{34} \mathrm{~S}$ values near 20\% 


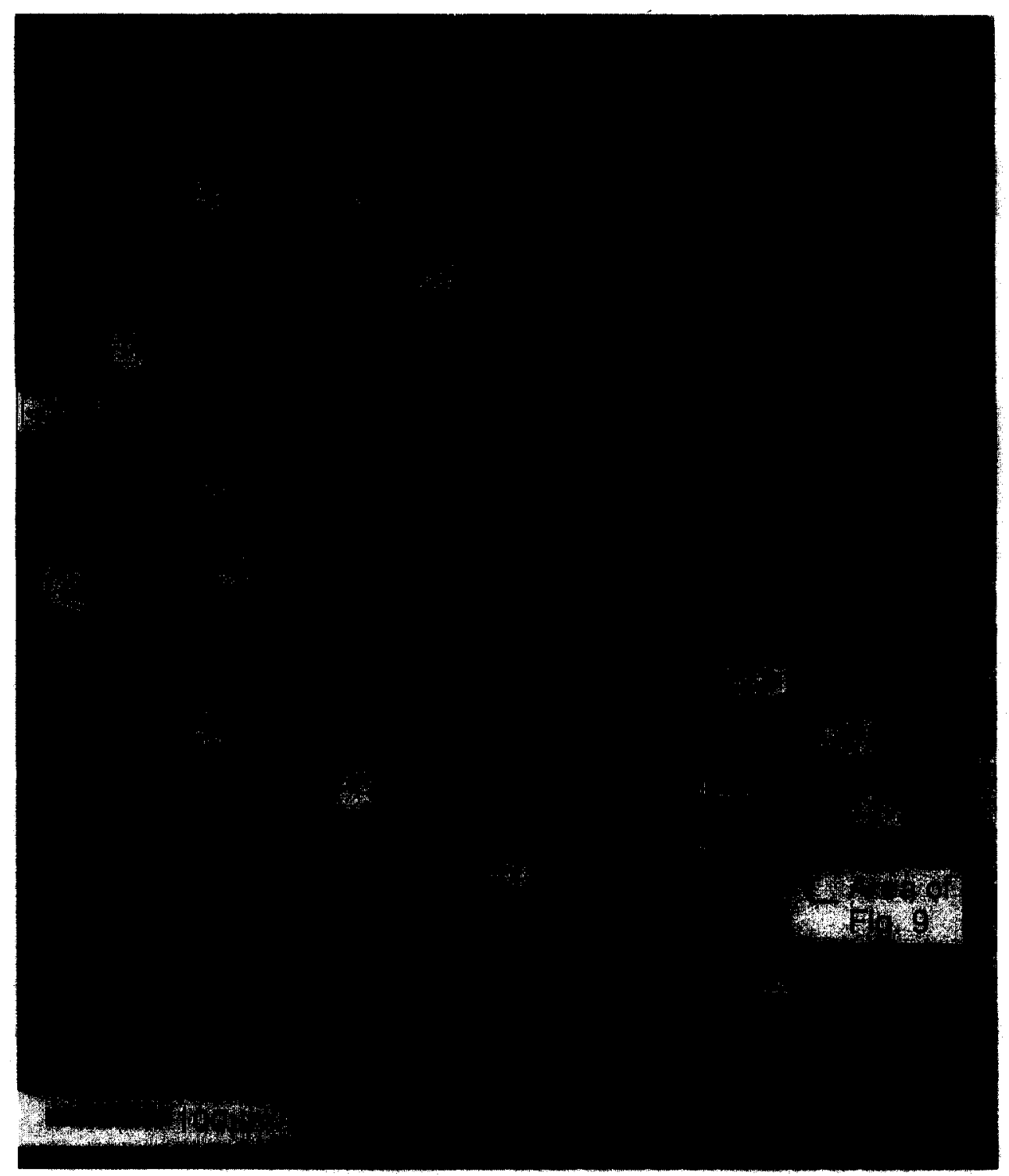

FIG. 8. Backscattered electron photomicrograph of sample 1154, Cube I. Analytical symbols as for Fig. 5. Black areas are quartz (lower left) or voids in the sample. Three major episodes of pyrite overgrowth on the large cube are evident; variations in shades of grey are indicative of the As content of the pyrite. The approximate area of Fig. 9 is shown by the rectangle at the lower right of the photograph.

( uncertainties are estimated to be $\pm 4 \%$, given analytical uncertainties and relative volume contribution uncertainties). Overgrowth arsenian pyrite (Fig. 10 ) has very low $\delta^{34} \mathrm{~S}$ values $(-25 \%)$, consistent with analyses from Cube I.

\section{DISCUSSION}

Textures and mineralogy indicate that there were three distinct major periods of iron sulfide precipitation: preore pyrite (including both diagenetic sedimentary pyrite and igneous pyrite); pyrite and arsenopyrite associated with $\mathrm{Au}$ deposition; and open space-filling or breccia coating, Au-free, pyrite. All three generations may be closely intergrown in any given sample and yield little more than mixed results to any conventional study. The results of the in situ analytical techniques permit the correlation of critical elemental zoning data ( $\mathrm{Au}, \mathrm{As}$ ) with $\delta^{34} \mathrm{~S}$ measurements. The data presented herein illustrate that each depositional period of iron sulfide had its own geochemical characteristics. Such geochemical characteristics, which are critical to understanding Au transportation and depositional mechanisms, could have been elucidated only by microanalytical techniques.

\section{Isotopic Character of Main-stage Ore Fluids}

The ore fluid had high $\delta^{34} \mathrm{~S}$ values $(\sim 20 \%$ ), and only a single stage of $\mathrm{Au}$ mineralization is required by our data. Fluctuations in the arsenic content of zoned mineral grains suggest that some changes occurred in fluid chemistry during the mineralization event, although correlative fluctuations in sulfur isotope compositions have yet to be demonstrated. Earliest hydrothermal sulfides (arsenopyrite, arsenian pyrite) 

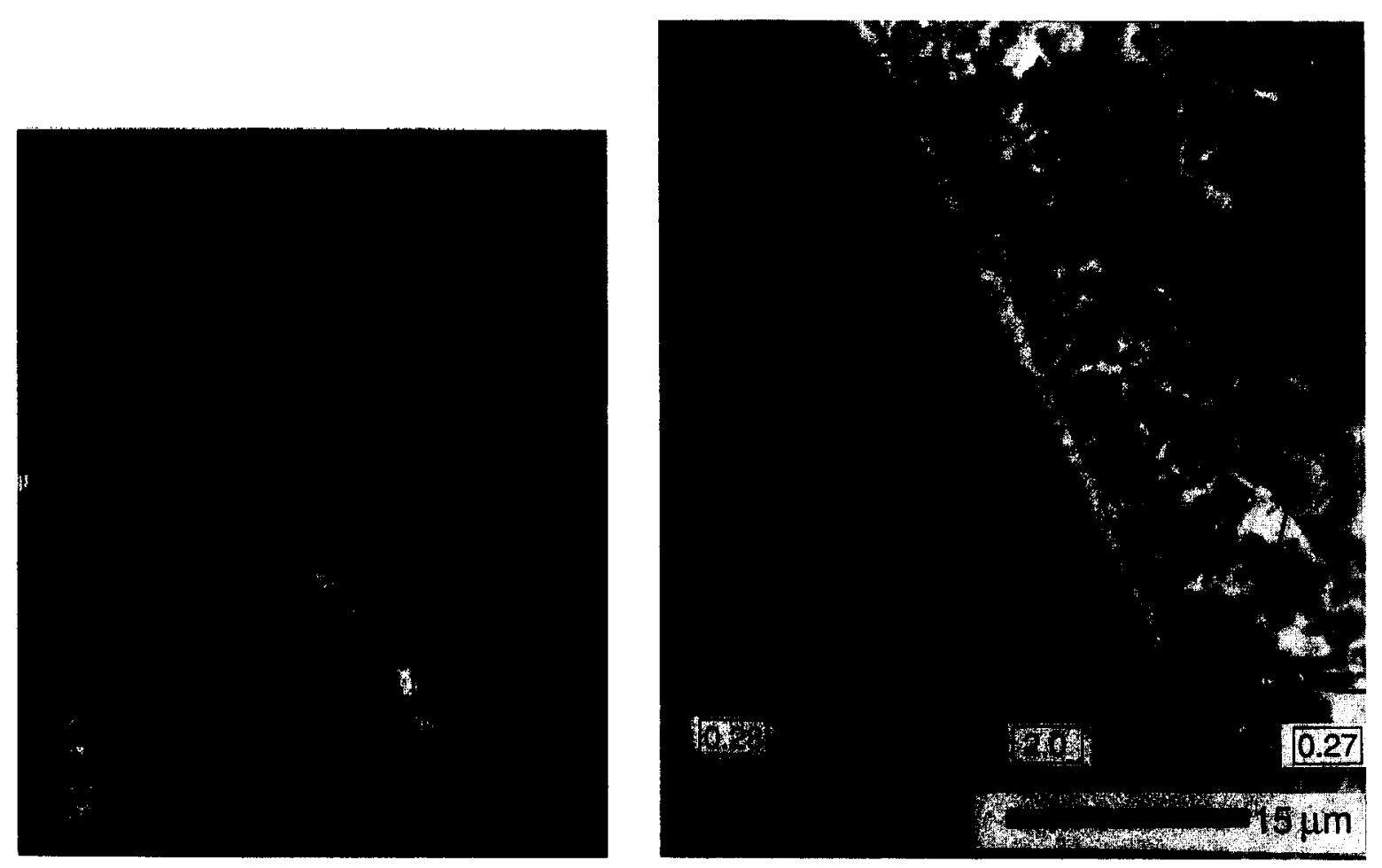

FIG. 9. Enlargement of the margin of pyrite cube of Fig. 8. Analytical symbols as for Fig. 5. (a) Secondary ion mass map for mass $197(\mathrm{Au})$. Most of the $\mathrm{Au}$ is in a thin band on the edge of the pyrite cube. (b) Backscattered electron photomicrograph of the same area. Dashed circles indicate the approximate areas of each spot analyzed for Au. Because of the extreme contrast across, and small size of the Au-bearing band, the sulfur isotopic composition of this band has not been determined.

that contain the majority of the Au are quite uniform isotopically, with $\delta^{34} \mathrm{~S}$ values near $20 \%$. This uniformity is demonstrated by the similarity of isotopic signatures from Au-bearing arsenian pyrite from widely separated parts of the orebody. Slightly lower values reported for some samples represent contamination by wall rock sulfur. As the ore fluids were isolated from further reaction or mixing with the wall rock sulfur through time, the latest deposited material probably is a more accurate reflection of the true isotopic composition of the hydrothermal fluid. Fluid contamination may explain the apparent isotopic zoning in the vein material from sample 1751 (Fig. 5). Sample 838 records the influx of such a fluid having a high $\delta{ }^{34} \mathrm{~S}$ value; as preore pyrrhotite was converted to marcasite and pyrite by addition of sulfur, the isotopic values of the latter minerals reflect contributions from both pyrrhotite sulfur $(\sim 5 \%$ ) and the ore fluid $(\sim 20 \%$ ) to yield intermediate $\delta^{34} \mathrm{~S}$ values $(\sim 8-12 \%)$. In contrast to the ore-stage sulfides, preore sulfides in the mine area generally have lower $\delta^{34} \mathrm{~S}$ values (Goldstrike stock, 4-9\%; diagenetic sedimentary pyrite, -5 to $9 \% 0$ ). Late-stage hydrothermal arsenian pyrite has even lower $\delta^{34} \mathrm{~S}$ values $(-12$ to $-29 \%)$.

\section{Source of Sulfur}

Three sources of hydrothermal sulfur are possible for these ores: sulfur from igneous sources, sedimentary diagenetic sulfides (dominantly pyrite), and lower Paleozoic seawater sulfates (at present represented by bedded barite). Sulfides from igneous sources generally have $\delta^{34} S$ values near $0( \pm 5) \%$ (Онмото and RYE, 1979). Sedimentary sulfides from unmineralized sedimentary rocks in the lower Paleozoic section in northern Nevada have $\delta^{34} \mathrm{~S}$ values between 3 and $15 \%$ (RYE, 1985); within the Post/Betze deposit the range of $\delta^{34} \mathrm{~S}$ values of preore pyrite extends at least as low as $-6 \%$ (Tables 1 and 2). Bedded barite deposits in Nevada have $\delta^{34} \mathrm{~S}$ values ranging from $0-60 \%$; the majority of these samples, however, have values between 20 and 35\% (RYE et al., 1978; PAPKE, 1984; AREHART et al., 1993a; G. B. Arehart, unpubl. data) encompassing the range of seawater sulfate for lower Paleozoic time (CLAYPOOL et al., 1980). Although sulfate-bearing brines would also have isotopic compositions similar to those of sedimentary sulfates, such fluids are unlikely to have remained in the section until the time of mineralization. Brines, along with hydrocarbons, migrated out of the lower Paleozoic rocks before or during Triassic metamorphism ( PoOLE et al., 1983). Therefore, they are not considered possible sulfur sources. However, evaporation of these brines during metamorphic events could have resulted in deposition of disseminated sulfates which would have isotopic compositions similar to seawater sulfate.

Pyrite from the Goldstrike stock has high $\delta^{34} \mathrm{~S}$ values (4$9 \%$; Tables 1 and 2 ) compared to those of most igneous sulfide, possibly as a result of incorporation of sedimentary sulfate from the Paleozoic section. These values are significantly 


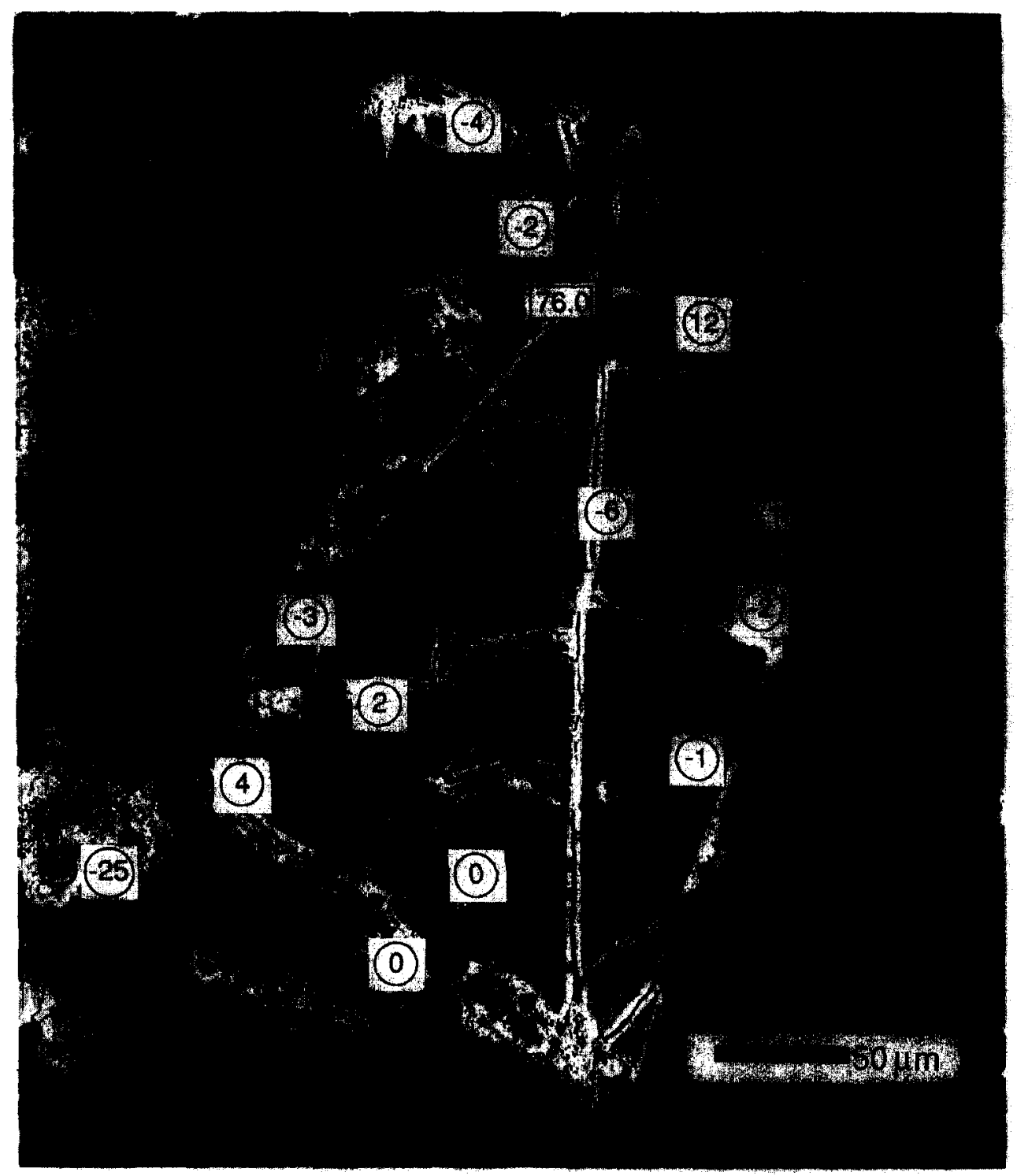

FIG. 10. Backscattered electron photomicrograph of sample 1154, Cube II. Analytical symbols as for Fig. 5. Arsenicenriched areas in fractures also are enriched greatly in Au over the preexisting pyrite. Arsenic-enriched overgrowths (partially shown in the left margin of the photograph) are the same as those of Fig. 8 and contain no $\mathrm{Au}$. Sulfur isotope analyses which include As-enriched zones along fractures also have high ${ }^{34} \mathrm{~S}$ values (up to $12 \%$ ). By estimation of the contribution of the primary vs. replacement sulfur for each analysis, the $\mathrm{Au}$ - and As-bearing material has $\delta^{34} \mathrm{~S} \approx 20 \%$. Overgrowth arsenian material has low ${ }^{34} \mathrm{~S}$ values, consistent with analyses from Cube 1.

lower than the measured sulfur isotope composition of $\sim 20 \%$ for ore-depositing fluids. The similarity between sulfur isotope values of unaltered sedimentary rock sulfides and conventional bulk analyses of sulfur isotopes from SHDG deposits has been interpreted as evidence that hydrothermal solutions obtained their sulfur from sedimentary rock pyrite (RYE, 1985). However, $\delta^{34} \mathrm{~S}$ values as high as $20 \%$ have not been observed previously in Au-bearing sulfides. Bulk analyses are likely to be biased by incorporation of non-ore-stage pyrite and might not reflect the truc composition of the ore fluids. $\delta^{34} \mathrm{~S}$ values of bedded barite from the lower Paleozoic section in the vicinity of the Post/Betze deposit range from 20-30\%, with a few samples as high as 38\% (RADTKE, 1985; AREHART et al., 1992; G. B. Arehart, unpubl. data). Results presented here suggest that thermochemically reduced barite (or other sedimentary sulfates) from the Paleozoic section may have been a major (though not necessarily the sole) source of sulfur for transporting solutions.

\section{Isotopic Character of Late-stage Ore Fluids}

In one sample ( 1154 ), several stages of late arsenian pyrite do not contain $\mathrm{Au}$ and have extremely low $\delta^{34} \mathrm{~S}$ values. The isotopic signature of these late-stage arsenian pyrite bands in sample 1154 suggests either that oxidation occurred (in several episodes as each band must represent a single event), or that a second fluid with a radically different isotopic signature from the main ore-stage fluids was introduced. Theoretical 
calculations of Rayleigh fractionation (e.g., equations of VALLEY, 1986) of sulfur isotopes indicate that oxidation, possibly due to boiling and consequent loss of $\mathrm{H}_{2}$, has the potential to produce radical fractionations and result in hydrothermal solutions with extremely low $\delta^{34} \mathrm{~S}$ values of sulfide in solution (e.g., MCKIBBEN and ELDRIDGE, 1990). As applied to the Post/Betze samples described herein, these calculations require that approximately $82 \%$ of the $\mathrm{H}_{2} \mathrm{~S}$ in the fluid be effectively removed (by boiling or oxidation to sulfate) to shift the sulfur isotope composition of the remaining $\mathrm{H}_{2} \mathrm{~S}$ in solution by $50 \%$ at $200^{\circ} \mathrm{C}$ (a temperature thought reasonable for the formation of SHDG deposits; Fig. 11). Because equilibrium between sulfate and sulfide is rarely established at temperatures below $\sim 300^{\circ} \mathrm{C}$ (ОНMOTO and LASAGA, 1982), $\mathrm{H}_{2} \mathrm{~S}$ will always behave as if it is in an open system, even if removal of $\mathrm{H}_{2} \mathrm{~S}$ does not occur due to boiling. Simple calculations, including the following equilibria (from OHMOTO et al., 1983),

$\mathrm{FeS}_{2}+2 \mathrm{H}^{+}+16 \mathrm{H}_{2} \mathrm{O}+\mathrm{SO}_{4}^{-2}=4 \mathrm{Fe}_{2} \mathrm{O}_{3}+17 \mathrm{H}_{2} \mathrm{~S}+4 \mathrm{O}_{2}$

$$
\begin{aligned}
\log \mathrm{K}\left(200^{\circ} \mathrm{C}\right) & =-219.3 \\
\mathrm{H}_{2} \mathrm{~S}+2 \mathrm{O}_{2}=2 \mathrm{H}^{\prime}+\mathrm{SO}_{4}^{-2} \log \mathrm{K}\left(200^{\circ} \mathrm{C}\right) & =66.63,
\end{aligned}
$$

indicate that as long as the total sulfur content of the solution remains above $\sim 10^{-4} \mathrm{~mol} / \mathrm{L}$, pyrite will remain stable even though a large fraction of the $\mathrm{H}_{2} \mathrm{~S}(>90 \%)$ is oxidized to sulfate (Fig. 12). This fluid isotopic signature could be preserved in pyrite zonation such as that described by MCKJBBEN and ELDRIDGE (1990); however, documented cases of this preservation are rare.

Perhaps more common is that case where oxidation occurs and the fluid remains in the pyrite stability field but is not

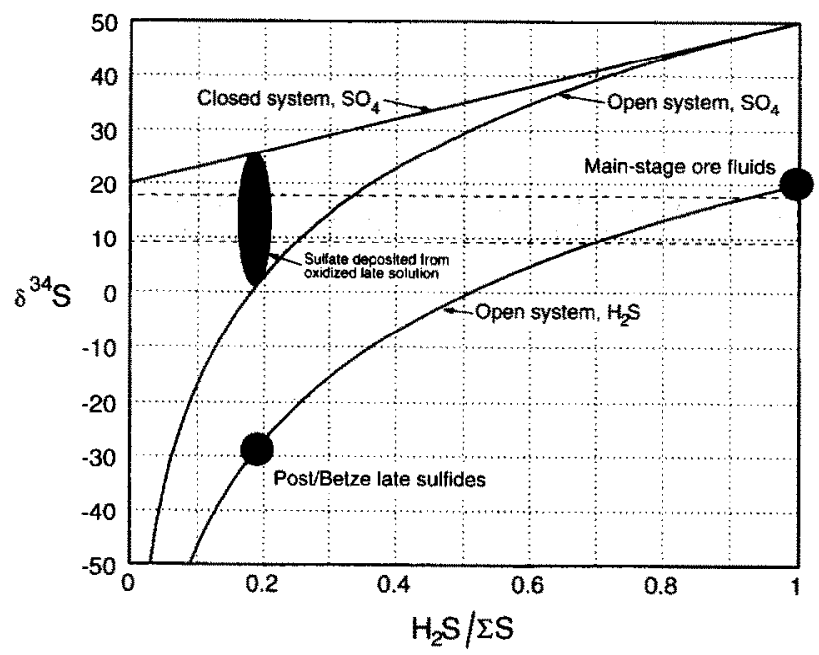

FIG. 11. Theoretical model of Rayleigh fractionation based on the equations of VALLEY (1986). Main-stage ore fluids are assumed to have an isotopic composition of $20 \%$, and open-system behavior of $\mathrm{H}_{2} \mathrm{~S}$ is assumed (sce text). Isotopic composition of the must ${ }^{34} \mathrm{~S}$ depleted late-stage fluids requires oxidation or removal of $82 \%$ of the original $\mathrm{H}_{2} \mathrm{~S}$. Resultant sulfate compositions should fall between 0 and $25 \%$ (i.e., between the open- and closed-system curves). The range of barite sulfate compositions from late-stage veins at Post/ Betze is shown by the light grey shaded region between dashed lines.

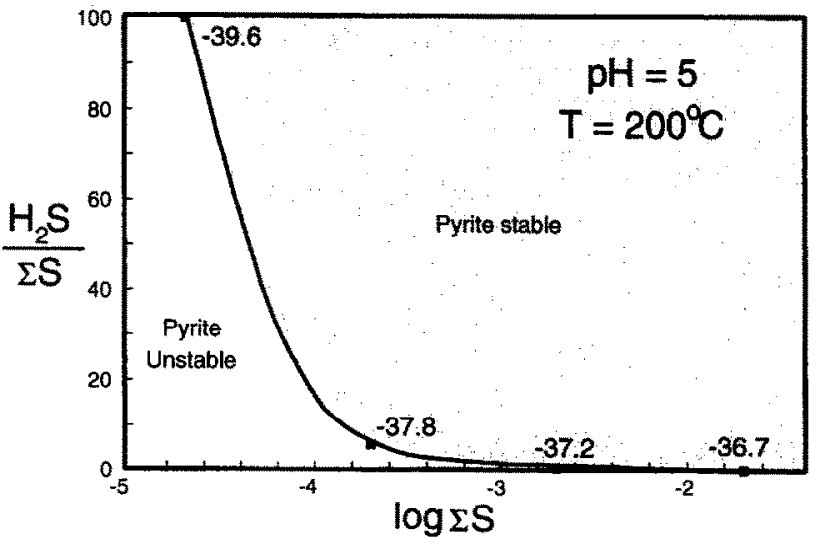

FIG. 12. Plot of $\mathrm{H}_{2} \mathrm{~S} / \mathrm{\Sigma S}$ vs. $\Sigma \mathrm{S}$ for reactions described in text. Vertical axis represents the fraction of total $S$ required to be $\mathrm{H}_{2} \mathrm{~S}$ to stabilize pyrite. Numbers adjacent to curve are $f_{\mathrm{O}_{2}}$ values. Changes in pH between 4 and 6 do not appreciably shift the curve.

actively depositing pyrite. In such a case, there may be no record in the isotopic compositions of sulfide minerals of the radical shifts in isotopic composition of the fluid. Some significant perturbation of the system is required to cause pyrite deposition from these solutions and consequent recording of the isotopic signature of the fluid. One mechanism by which such a perturbation may occur is incursion and mixing of iron-rich fluids with the hydrothermal fluid, exceeding the solubility of pyrite and causing additional pyrite deposition. These phenomena would be most common in highly permeable zones, such as the breccias in sample 1154 .

Because As concentrations (and As solubilities) are much greater than those of $\mathrm{Au}$, it is likely that late fluids may still contain significant As concentrations but be depleted in $\mathrm{Au}$. Such effects are clear from zoning and paragenetic studies discussed above in that most gold was deposited before As was completely depleted from the fluid.

If Rayleigh fractionation occurs because of oxidation of $\mathrm{H}_{2} \mathrm{~S}$ in either open or closed systems, resultant $\delta^{34} \mathrm{~S}$ values of sulfate in the fluid also will decrease through time. Depending upon the relative effectiveness of equilibrium vs. nonequilibrium processes, the $\delta^{34} \mathrm{~S}$ value of sulfate in solution will fall between these two extremes. Therefore, any sulfate minerals deposited will have $\delta^{34} \mathrm{~S}$ values between 0 and $25 \%$ if formed from the same solutions which deposited the sulfide having $\delta^{34} S$ values of $-30 \%$ (Fig. 11 ).

In fact, such a process may be recorded in hydrothermal barite from SHDG deposits. Late-stage barite crystals from Post/Betze, which were deposited in the same veins and breccias as sulfides having low $\delta^{34} S$ values (Fig. 3), have lower $\delta^{34} \mathrm{~S}$ values than early nonvein barite (AREHART et al., 1992). Although this barite could have formed as a result of quantitative oxidation of the original hydrothermal solutions, this alternative is considered unlikely because of the significant difference in their positions in the paragenetic sequence. Barite deposited early in the paragenetic sequence has $\delta^{34} S$ values in excess of $25 \%$. Similar trends in $\delta^{34} \mathrm{~S}$ values of barite are observed at Alligator Ridge (ILCHIK, 1990), Gold Quarry, and Rain (G. B. Arehart, unpubl. data). 
In summary, sulfide and sulfate mineral $\delta^{34} \mathrm{~S}$ values from Post / Betze are compatible with oxidation (possibly boiling) during late-stage hydrothermal events followed by an influx of $\mathrm{Fe}$-rich solutions and mixing to cause pyrite deposition. Although we favor the oxidation/mixing hypothesis, the data do not rule out the possible incursion of a second fluid, unrelated to Au mineralization and having a distinct isotopic character.

\section{CONCLUSIONS}

The data presented here show the power of applying paired ion probe measurements of elemental and isotopic concentrations in elucidating geochemical processes on fine-grained samples. The essentially nondestructive technique allows post-analytical examination of the sample and further measurements to be made if necessary. Results presented in this paper are interpreted to indicate that fluids responsible for gold deposition at Post/Betze had high $\delta^{34} S$ values, signifcantly higher than previously measured. These high values are thought to have arisen from thermochemical reduction of seawater-derived sulfate. Whether this is a modification of the ore fluids near the depositional site because of the local abundance of bedded barite or whether SHDG fluids in general have high $\delta^{34} S$ values is unclear and must await further analytical work on similar deposits in terranes having lower local contents of sedimentary sulfate. Extremely low $\delta^{34} \mathrm{~S}$ values of late-stage hydrothermal minerals and, by inference, fluids may be the manifestation of a shift from reducing to oxidizing conditions. Alternatively, these fluids may represent a completely separate event, having a unique isotopic character.

Acknowledgments-Samples for this study were obtained by the senior author with the consent of American Barrick Resources and Newmont Mining $\mathrm{Co}$. This work was supported financially by grants from the National Science Foundation (EAR-89-05107) and the University of Michigan Scott Turner Fund. Discussions with Henry Jones, Jeff Alt, and Joe Graney clarified several points. Reviews of the paper by J. K. Böhlke, R. O. Rye, M. A. McKibben, and an anonymous Geochimica et Cosmochimica Acta reviewer aided greatly in improving and clarifying the manuscript.

Editorial handling: T. S. Bowers

\section{REFERENCES}

Arehart G. B., Kesler S. E., O'Neil J. R., Eldridge C. S., and CHRYSSOULIS S. L. (1991) Elemental and sulfur isotopic zoning in iron sulfide grains from sediment-hosted micron gold deposits: Implications for deposit genesis. GSA Abstr. Prog. 23, A226 (abstr.).

ARehart G. B., Kesler S. E., O'Neil J. R., and Foland K. A. (1992) Evidence for the supergene origin of alunite in sedimenthosted micron gold deposits. Nevada. Econ. Geol. 87, 263-270.

Arehart G. B., Chryssoulis S. L., and Kesler S. E. (1993a) Gold and arsenic in iron sulfides from sediment-hosted disseminated gold deposits: Implications for depositional processes. Econ. Geol. (in press).

ARehart G. B., Foland K. A., NaEser C. W., and Kesler S. E. (1993b) Geology and geochronology of sediment-hosted micron gold deposits adjacent to the Goldstrike stock, northeastern Nevada. Econ. Geol. (in press).

BAKKEN B. M. and EINAUDl M. T. (1986) Spatial and temporal relation between wall rock alteration and gold mineralization, main pit, Carlin gold mine, Nevada, USA. In Gold' 86 (ed. A. J. MACDONALD), pp. 388-403. Konsult Intl. Inc.

BAKKeN B. M., HOCHELla. M. F., JR., MARShall A. F., and TURNER A. M. (1989) High-resolution microscopy of gold in unoxidized ore from the Carlin Mine, Nevada. Econ. Geol. 84, 171-179.

Bakken B. M., Brigham R. H., and Fleming R. H. (1991) The distribution of gold in unoxidized ore from Carlin-type deposits revealed by secondary ion mass spectrometry (SIMS). GSA Abstr. Prog. 23, A228.

Bettles K. H. (1989) Gold deposits of the Goldstrike mine, Carlin trend, Nevada. Soc. Mining Eng. Preprint 89-158.

Cathlineau M., Boiron M., Holliger P., Marion P., and Denis M. (1988) Gold in arsenopyrites: Crystal chemistry, location and state, physical and chemical conditions of deposition. Econ. Geol. Monog. 6, pp. 328-341.

Chao E. C. T., Minkin J. A., Back J. M., Chen J. R., Bagby W. C., Rivers M. L., Sutton S. R., Hanson A. L., Gordon B. M., and JONES D. W. (1986) Occurrence of gold in an unoxidized Carlin-type ore sample-a preliminary synchroton and micro-optical restudy. GSA Absir. Prog. 18, 562.

CHRYSSOULIS S. L. (1990) Detection and quantification of "invisible" gold by microprobe techniques. In Gold ' 90 (ed. D. M. HAUSEN), pp. 323-332. Soc. Mining Eng.

Chryssoulis S. L., CABRi L. J., and Salter R. S. (1987) Direct determination of invisible gold in refractory sulphide ores. Proc Intl. Symp. on Gold Metallurgy-Refractory Gold, pp. 235-244.

Chryssoulis S. L., CABRI L. J., and LenNARD W. (1989) Calibration of the ion microprobe for quantitative trace precious metal analyses of ore minerals. Econ. Geol. 84, 1684-1689.

Claypool G. E., Holser W. T., Kaplan I. R., Sakai H., and ZaK 1. (1980) The age curves of sulfur and oxygen isotopes in marine sulfate and their mutual interpretation. Chem. Geol. 28, 199-260.

EldRIDGE C. S., COMPSTON W., Williams I. S., WALSHE J. L., and BOTH R. A. (1987) In situ microanalysis for ${ }^{32} \mathrm{~S} /{ }^{34} \mathrm{~S}$ ratios using the ion microprobe SHRIMP. Intl. J. Mass Spectr. Ion Proc. 76, 65-83.

EldRidge C. S., COMPSton W., Williams I. S., and Walshe J. L. (1989) Sulfur isotope analyses on the SHRIMP ion microprobe. USGS Bull. 1890, pp. 163-174.

Evans J. G. (1980) Geology of the Rodeo Creek NE and Welches Canyon quadrangles, Eureka County, Nevada. USGS Bull. 1473 , pp. 1-81.

Fleet M. E., Maclean P. J., and Barbier J. (1988) Oscillatoryzoned As-bearing pyrite from stratabound and stratiform gold deposits: An indicator of ore fluid evolution. Econ. Geol. Monogr. 6. pp. 356-362.

HAUSEN D. M. and KERR P. F. (1968) Fine gold occurrence at Carlin, Nevada. In Ore Deposits of the United States (ed. J. D. RIDGE), pp. 908-940. AIME.

HAUSEN D. M. and PARK W. C. (1985) Observations on the association of gold mineralization with organic matter in Carlin-type ores. Denver Region Expl. Geol. Soc. Symp. Proc. 3, 119-136.

Hausen D. M., Ahlrichs J. W., Mueller W., and Park W. C. (1987) Particulate gold occurrences in three Carlin carhonaceous ore types. In Process Mineralogy, Vol. VI(ed. R. D. HAGNI), pp. 193-214. Metall. Soc. AIME.

Hofstra A. H., Northrop H. R., Rye R. O., LANDis G. P., and BIRAK D. J. (1988) Origin of sediment-hosted disseminated gold deposits by fluid mixing-evidence from jasperoids in the Jerritt Canyon gold district, Nevada, USA. Gold' 88 Proc. Vol., pp. 284289.

ILCHIK R. P. (1990) Geology and geochemistry of the Vantage gold deposits, Alligator Ridge-Bald Mountain mining district, Nevada. Econ. Geol. 85, 50-75.

JORALEMON P. (1951) The occurrence of gold at the Getchell mine, Nevada. Econ. Geol. 46, 267-310.

KUEHN C. A. ( 1989) Studies of disseminated gold deposits near Carlin, Nevada: Evidence for a deep geologic setting of ore formation. Ph.D. thesis, Pennsylvania State Univ.

MCKIBBEN M. A. and ELDRIDGE C. S. (1990) Radical sulfur isotope 
zonation of pyrite accompanying boiling and epithermal gold deposition: A SHRIMP study of the Valles Caldera, New Mexico. Econ. Geol. 85, 1917-1925.

OHMOTO H. and LASAGA A. C. (1982) Kinetics of reactions between aqueous sulfates and sulfides in hydrothermal systems. Geochim. Cosmochim. Acta 46, 1727-1745.

OHмOTO H. and RYE R. O. (1979) Isotopes of sulfur and carbon. In Geochemistry of Hydrothermal Ore Deposits (ed. H. L. BARNES), pp. 509-567. J. Wiley \& Sons.

Ohmoto H., Mizukami M., Drummond S. E., Eldridge C. S., Pisutha-ARnond V., and Lenagh T. C. (1983) Chemical processes of Kuroko formation. Econ. Geol. Monogr. 5, pp. 570-604.

PAPKE K. G. ( 1984) Barite in Nevada. Nevada Bur. Mines and Geol. Bull. 98.

PoOle F. G., Claypool G. E., and Fouch T. D. (1983) Major episodes of petroleum generation in part of the northern Great Basin, In The Role of Heat in the Development of Energy and Mineral Resources in the Northern Basin and Range Province: Special Report No. 13, pp. 207-213. Geothermal Resources Council, Davis, CA.

RADTKE A. S. (1985) Geology of the Carlin gold deposit, Nevada. USGS Prof. Paper 1267.

RADTKE A. S., TAYloR C. M., and Christ C. L. (1972) Chemical distribution of gold and mercury at the Carlin deposit, Nevada. GSA Abstr. Prog. 4, 632 (abstr.).

RADTKE A. S., RYE R. O., and Dickson F. W. (1980) Geology and stable isotope studies of the Carlin gold deposit, Nevada. Econ. Geol. 75, 641-672.

ROBINSON B. W. and KUSAKABE M. (1975) Quantitative preparation of sulfur dioxide, for ${ }^{34} \mathrm{~S} /{ }^{32} \mathrm{~S}$ analyses, from sulfides by combustion with cuprous oxide. Anal. Chem. 47, 1179-1181.

RYE R. O. (1985) A model for the formation of carbonate-hosted disseminated gold deposits based on geologic, fluid inclusion, geochemical, and stable isotope studies of the Carlin and Cortez deposits, Nevada. USGS Bull. 1646, pp. 35-42.

RYE R. O., SHAWE D. R., and PoOlE F. G. (1978) Stable isotope studies of bedded barite at East Northumberland Canyon in Toquima Range, central Nevada. J. Res. USGS 6, 221-239.

RYTUBA J. J. ( 1985 ) Geochemistry of hydrothermal transport and deposition of gold and sulfide minerals in Carlin-type gold deposits. USGS Bull. 1646, pp. 27-34.

VALLEY J. W. (1986) Stable isotope geochemistry of metamorphic rocks. Rev. Mineral. 16, 445-489.

WeLLS J. D. and MuLLENS T. E. (1973) Gold-bearing arsenian pyrite determined by microprobe analysis, Cortez and Carlin gold mines, Nevada. Econ. Geol. 68, 187-201. 